\title{
Creating entrepreneurial networks: academic entrepreneurship, mobility and collaboration during PhD education
}

Dzamila Bienkowska and Magnus Klofsten

\section{Linköping University Post Print}

N.B.: When citing this work, cite the original article.

The original publication is available at www.springerlink.com:

Dzamila Bienkowska and Magnus Klofsten, Creating entrepreneurial networks: academic entrepreneurship, mobility and collaboration during $\mathrm{PhD}$ education, 2012, Higher Education, (64), 2, 207-222.

http://dx.doi.org/10.1007/s10734-011-9488-x

Copyright: Springer Verlag (Germany) http://www.springerlink.com/?MUD=MP

Postprint available at: Linköping University Electronic Press http://urn.kb.se/resolve?urn=urn:nbn:se:liu:diva-75204 


\title{
Creating entrepreneurial networks: academic entrepreneurship, mobility and collaboration during PhD education
}

\author{
Dzamila Bienkowska \& Magnus Klofsten \\ Department of Management and Engineering and HELIX VINN Excellence Centre \\ Linköping University, 58183 Linköping, Sweden \\ e-mail: Dzamila.Bienkowska@liu.se
}

\begin{abstract}
Network-building activities of $\mathrm{PhD}$ students are an important area of study in furthering our understanding of academic entrepreneurship. This paper focuses on $\mathrm{PhD}$ students' participation in network-building activities defined as mobility and collaboration, as well as own interest in and perceived grade of support for commercialisation from various levels of the university hierarchy. The results of a large-scale survey (of 1,126 PhD students at Linköping University, Sweden, $41 \%$ response rate) presented here show that the majority of $\mathrm{PhD}$ students are engaged in collaborations with external organisations, though quite few (one quarter) have spent a part of their $\mathrm{PhD}$ education outside their home university. PhD students from all faculties are on average interested in commercialisation and in favour of it. However, PhD students from the faculty of Health Sciences state that it is difficult for them to combine research and commercialisation. Furthermore, interest in commercialisation of research results is relatively lowest amongst those $\mathrm{PhD}$ students who are undertaking mobility placements at other universities, thus pointing to an experienced incompatibility of research and academic entrepreneurship.
\end{abstract}

\section{Keywords}

Academic entrepreneurship; Mobility; Collaboration; Network-building activities; PhD education; University-industry networks; Commercialisation of research

\section{Introduction}

Since the concept of entrepreneurial university was introduced in the beginning of the 1980 s the manner in which higher education institutions can contribute to wealth and economic growth has generated a lot of interest (Etzkowitz 1983; Cowen 1991; Clark 1998; Klofsten and Jones-Evans 2000; Gibb and Hannon 2006). Studies by authors such as Saxenian (1994) and Etzkowitz and Klofsten (2005) show that presence of a university over a long period of time can have positive effects on knowledge-based regional development. These effects are mediated through a multitude of processes such as commercialisation of research results and provision of highly educated entrepreneurially oriented individuals to the regional labour market. 
Therefore, it is not surprising that there have been a large number of initiatives developed world-wide to promote a broad range of entrepreneurial activities within academic institutions (Slaughter and Leslie 1997; Shane 2004). These include programmes to develop new organisations in the form of spin-off firms (Gartner 1988) as well as projects that link the university to businesses within the region (Bergek and Norrman 2008; Klofsten et al. 2010).

Over the last decade $\mathrm{PhD}$ education has come to constitute a considerable part of many universities' activities and $\mathrm{PhD}$ students today perform a large share of university research (Enders 2002). Therefore, understanding the $\mathrm{PhD}$ education process is crucial in order to assess the entrepreneurial orientation of the university and the prerequisites for contributing to knowledge-based regional development. Yet there are few studies concerned with PhD students' network-building activities or university context's support for academic entrepreneurship.

The aim of this paper is to investigate $\mathrm{PhD}$ education and the university context with regard to supportiveness of academic entrepreneurship and network-building activities defined as mobility and external collaborations. ${ }^{1}$ Following research questions are addressed specifically: (1) What are $\mathrm{PhD}$ students' attitudes towards commercialisation and entrepreneurship and how supportive is the university context in this regard? (2) Are mobile $\mathrm{PhD}$ students (that spend an extended period of time at a workplace outside their daily workplace at the university, for example a research lab or a private firm) more positive towards entrepreneurship and commercialisation than other PhD students? (3) Are PhD students involved in collaborative project with organisations outside their university more positive towards entrepreneurship and commercialisation than other PhD students?

The paper is structured as follows: the next section gives a theoretical background to academic entrepreneurship and the concept of entrepreneurial university. Subsequently, previous studies of mobility and collaboration during $\mathrm{PhD}$ education are presented. Thereafter the methods and data are described, followed by results and analysis. Finally, conclusions and implications are elaborated on.

\section{Towards the entrepreneurial university}

Over the past decades universities have been increasingly taking an active role in both economic and social development. This follows from a transition in the processes of knowledge production described as a move from Mode 1 to Mode 2 where a focus on application of science is a key characteristic

\footnotetext{
${ }^{1}$ This definition is in line with the argument by Jöns (2009) that shows how a long-term cumulative process of mobility and collaboration contributes to the development of post-war German academic system.
} 
(Gibbons et al. 1994). Whereas the traditional Mode 1 allowed for production of knowledge by autonomous researchers within strict boundaries set by disciplines, Mode 2 opens up knowledge production through transdisciplinarity as well as other border-spanning collaborations with a diversity of actors being actively involved in research (Nowotny et al. 2003). Several new forms for organising collaborations have been developed following the transition to Mode 2, often launched or supported by policy initiatives on various levels (Henkel 2000). These new forms might include technology transfer offices, long-term research programmes encompassing both basic and applied research,

interdisciplinary research centres and research institutes focused on specific sectors (Jacob 2001;

Bienkowska et al. 2010). The emerging system of dynamic relations between the spheres of university, industry and government that formed subsequently has been described as the "Triple Helix" model that emphasizes continuous transformations and non-synchronised activities involving all three groups of actors with an enhanced role for the universities (Etzkowitz and Leydesdorff 1995; 2000).

Many well-known universities, such as Stanford, MIT and Cambridge, have developed this leading role even further and can be characterised as entrepreneurial universities, hence becoming role models for other universities around the world. These entrepreneurial universities are not only providing highly skilled human capital and research resources, but also interacting with industry and external organisations in general as well as supporting commercialisation and transfer of technology and knowledge (Clark 1998).

The development towards the entrepreneurial university has also met resistance and criticism. One source of tension has been the discontentment of the faculties and departments concerning resources being directed away from their control and towards entrepreneurial activities both within and outside the university (Henkel 2000). Another contested aspect of this development has been the changing meaning of academic freedom stemming from increased collaborative and interdisciplinary research (Henkel 2005). Furthermore, there are concerns that interests of private firms are becoming too dominant at universities consequently threatening the academic freedom (Altbach 2001).

The university environment consists of several different groups of individuals that could act entrepreneurially; these are academic staff, general staff, $\mathrm{PhD}$ students as well as master and undergraduate students. One of the challenges in moving towards the entrepreneurial university is to facilitate these individuals' access to resources necessary when acting entrepreneurially. For example, in the Swedish academic system and particularity in science \& engineering there is a great interest in 
commercialisation of research results, but only a minority of university researchers actually commercialise their ideas (Magnusson et al. 2009).

Access to networks is a critical resource as many types of economic behaviour, including change of career path and exchange of information or tangible resources between actors, are influenced by social relations (Granovetter 1974; 1985). Entrepreneurial activities are likewise dependent on personal networks, as these can provide the necessary knowledge, employees or capital under conditions of uncertainty (Aldrich et al. 1987; Liebeskind et al. 1996; Zellner and Fornahl 2002; Shane and Cable 2002). Interaction with entrepreneurs in networks can also provide inspiration and "mental models" i.e. sets of entrepreneurial behaviours, attributes and consequences that can be observed and imitated by other network members (Fornahl 2003). However, the involvement of actors from both academia and industry in networks can be more difficult to achieve since there are considerable differences in the norms and modes of operation in universities and firms respectively (Dasgupta and David 1994; Klofsten and Jones-Evans 2000; Fisher and Atkinson-Grosjean 2002; Mosey et al. 2006).

When developing networks, mobility of individuals is an effective mechanism and can even be deemed essential for initial network formation to take place since it is a prerequisite for face-to-face meetings and interaction (Urry 2002; Bienkowska et al. 2011). Face-to-face communication is an important way of creating trust between individuals due to the investments of effort, money and time that are manifested when people come together (Storper and Venables 2004). It has also been shown that face-to-face contacts facilitate learning, provide motivation and are an effective mode of communication due to an increased capacity for interruption and feedback (Nohria and Eccles 1992; Storper and Venables 2004). As Urry (2002; p. 265) puts it, "mobility in general is central to glueing social networks together" and "connections derived from co-presence can generate relations of trust that enhance both social and economic inclusion”. Furthermore, mobility automatically involves immersion in a different environment thus providing a multi-faceted learning experience that cannot be attained in any other way (Carlson 1988).

Mobility between university and industry can be considered a special case due to the aforementioned differences in modes of operation. These differences mean that there is a greater need for interaction and co-presence in order to build trustful relationships and create valuable results. Santoro (2000) showed that higher relationship intensity between US universities and firms, defined as e.g. personnel exchanges, was linked to higher levels of tangible outcomes from the relationships. 
Starbuck (2001) maintains that industrial experience of academics involved in university-industry partnerships is an important success factor and that mobility through visits is a fruitful way of learning about each other's needs and wants. Additionally, as shown in Barnes et al. (2002) commitment, continuity, and trust-building through one-to-one contacts are crucial factors in order to achieve successful outcomes from university-industry relationships.

\section{An international overview of network-building activities during PhD education}

Since $\mathrm{PhD}$ students are undergoing a process of socialisation during the $\mathrm{PhD}$ education (Boden et al. 2011) and are the recruitment base for both universities and industry it can be considered especially important to support their network-building activities, such as mobility and collaboration. Furthermore, the prevalence of the triple helix model also results in a broader set of expectations being placed upon $\mathrm{PhD}$ education. Examples of such new expectations include industry demand for flexible workers able to assimilate knowledge from various sources and university demand for entrepreneurial skills and experience from practice outside the academic context (Thune 2010). However, there are also risks with mobility and extended industry links that one should be aware of, i.e. they could delay publication of research results and lead to tensions within the university (Harman 1999; Bond and Paterson 2005).

A number of studies analysing collaboration between industry and universities involving $\mathrm{PhD}$ students have been published to date (see Thune 2009 for an extensive overview), although this field of research is still in its early phase of development. Harman $(2002 ; 2004)$ has studied PhD students in Australia comparing those related to Cooperative Research Centres (which link research with industry and promote commercialisation skills) with those not related to such centres. It was found that CRCrelated $\mathrm{PhD}$ education was more common in disciplines such as engineering, science and medicine than in social sciences, arts \& humanities and education. The majority of both CRC-related and non CRCrelated $\mathrm{PhD}$ students stated that they like the idea of doing research in industry. The CRC-related $\mathrm{PhD}$ students displayed higher levels of satisfaction with their course experience than others, were more inclined to agree that their department is very good in its field and had more contact with their supervisors. They were also more optimistic about their career prospects (Harman 2002).

In France it has been reported that university-industry links in PhD education have been growing since mid 1990s, supported by various governmental initiatives (Paul and Perret 2001). PhD 
students partly or totally funded by industry are most common in science and technology and least common in arts \& humanities and social science.

A survey of PhD students involved in collaborative research projects between university and industry in the UK showed that informal factors such as enthusiasm of supervisors and communication between involved partners were most vital for perceived success of the projects rather than formal project management factors (Butcher and Jeffrey 2007). Another study that highlights the importance of supervision in collaborative research projects involving $\mathrm{PhD}$ students together with industrial partners showed that the experience was enriching for both industrial supervisors and $\mathrm{PhD}$ students, although less so for the academic supervisors (Salminen-Karlsson and Wallgren 2008).

In a recent study of PhD students within science and technology in Norway it was found that many research collaborations diminish in intensity over time due to lack of commitment from the involved actors. Although the collaborations loosen, the studied $\mathrm{PhD}$ students still manage to publish results and complete their own part of the project (Thune 2010).

An intensified way of collaboration where both trust and new skills can be developed consists of mobility placements of $\mathrm{PhD}$ students. There are various initiatives that use different approaches in order to stimulate mobility of $\mathrm{PhD}$ students during their education. Examples include The Prince of Wales Scholarship Programme (POWIS) which sponsors doctoral research hosted by firms in Wales, UK (University of Wales Global Academy 2011). A broad spectrum of mobility placements of PhD students is supported by the AgoraLink programme in Sweden. Within this programme PhD students together with their supervisors choose relevant organisations for two stints of mobility placements which are supported financially. One of these stints is required to be in industry and one in either other universities/research organisations or public sector agencies (Bienkowska and Klofsten 2009).

Mobility placements of $\mathrm{PhD}$ students at other universities are becoming increasingly prevalent and have been studied by several authors. The Chinese government started a Graduate Students Joint Training (GSJT) programme in 2007 where $\mathrm{PhD}$ students receive financing for staying at universities abroad during their dissertation work. The programme encompasses 10 percent of the PhD student population in China, i.e. $5000 \mathrm{PhD}$ students are supported annually (Li 2010). Kyvik et al. (1999) have studied mobility of Scandinavian PhD students to other research organisations abroad. They concluded that stays abroad often contribute to establishing useful new research contacts and increased international publishing as well as a positive development of the dissertation work. The common 
drawbacks of mobility included delays in thesis work and poor contact with the professors at visited organisations. The overall results pointed to the benefits being far greater than the negative experiences, however only a minority of Scandinavian $\mathrm{PhD}$ students was reported as staying abroad during their PhD education (Kyvik et al. 1999). A study of mobility of PhD students from Italy to research organisations abroad also concluded that it is most often a positive experience (Avveduto 2001). It helps develop competence as well as flexibility through immersion in a new scientific and cultural environment. Nevertheless, only 28 percent of the PhD students had been internationally mobile as part of their doctoral education. Insufficient funding was the most common obstacle to staying abroad (Avveduto 2001).

As seen in the studies presented above mobility is often treated separately from collaborations and university-industry contacts are studied separately from contacts between universities and other research organisations. These types of network-building activities share a lot of similar traits such as interaction with a different cultural and institutional context and promotion of a flexible mindset. They are also subject to similar obstacles, for example lack of time, funding or internal support. Therefore, this paper encompasses these both types of network-building activities simultaneously thus offering a new perspective on $\mathrm{PhD}$ education and contributing to the field of academic entrepreneurship.

\section{Method and data}

This study is based on data from a survey of PhD students at Linköping University, Sweden. A webbased questionnaire was sent out in April 2010 to all current PhD students (1126 persons) of which 464 $(41 \%)$ responded.

The questionnaire was organised in four sections starting with general background information about respondents' age, gender, nationality, as well as experiences from entrepreneurship, working life and voluntary organisations. In section two questions about students' opinions towards commercialisation of research results were asked. A 7-point Likert-like scale was used to measure attitudes towards seven items including possibilities to combine research and commercialisation and entrepreneurial intent.

In the third section attitudes towards university context's supportiveness of commercialisation activities were measured also using a 7-point scale. Six items related to the different levels of the university hierarchy were tested. Finally, in the fourth section questions about collaborations with external actors and mobility placements during $\mathrm{PhD}$ education (e.g. time spent at other organisations) 
were asked. The collected data was analysed in SPSS using quantitative methods such as Analysis of Variance and Pearson Chi-Square tests.

\section{Results and analysis}

\subsection{Sample characteristics}

The data presented in this study derive from $\mathrm{PhD}$ students from all four faculties at Linköping University. The average age of respondents is 28.1 years and $235(50.8 \%)$ are female while 228 (49.2\%) are male. Due to the small number of $\mathrm{PhD}$ students at the faculty of Educational Sciences its results are presented together with the faculty of Arts and Humanities (which at Linköping University includes Social Sciences). The distribution of respondents between faculties is as follows: 104 (22.6\%) $\mathrm{PhD}$ students from the faculty of Arts and Humanities (including Social and Educational Sciences), 158 (34.3\%) from Health Sciences, and 199 (43.2\%) from Science and Engineering.

Most of the respondents $(340 ; 72.8 \%)$ have had more than a year's worth of working experience before starting the $\mathrm{PhD}$ education. Approximately one third (31.4\%) have been holding a leading position (e.g. group leader, manager or chairman) in a business or organisation. Furthermore, over half $(301 ; 64.5 \%)$ of the respondents have been active in voluntary or non-profit organisations and in $174(57.6 \%)$ cases they have held a leading position in such organisations. $63(13.5 \%)$ have started their own business, and more than half of the respondents $(270 ; 58.2 \%)$ have relatives running a business (currently or previously).

\subsection{Opinions about entrepreneurship and the university context}

A first step of the analysis was to investigate the $\mathrm{PhD}$ students' opinions about commercialisation of research results (CRR) and perceived supportiveness of the university context with regard to entrepreneurship. As shown in the first four rows of Table 1 the students from all faculties have a slightly positive mindset towards CRR (the average scores range between 3.87 and 5.99) and the majority of scores are over 4 . The highest scores are consistently found in the faculty of Science \& Engineering (the average scores range between 4.55 and 5.99). Relatively, the least positive students are found in the faculty of Arts \& Humanities, including Social and Educational Sciences (the average scores range between 4.06 and 4.85). It can be noted that $\mathrm{PhD}$ students from the faculty of Health Sciences consider it least possible to combine research and CRR, although they are fairly highly in favour of commercialisation and have relatively high willingness to CRR. 
Table 1. Opinions and perceived context concerning commercialisation of research results (tested for significant differences between groups).

\begin{tabular}{|c|c|c|c|c|}
\hline Opinions \& Context & $\begin{array}{l}\text { Arts \& } \\
\text { Humanities } \\
\text { (including } \\
\text { Soc. and } \\
\text { Educ. Sci.) }\end{array}$ & $\begin{array}{l}\text { Health } \\
\text { Sciences }\end{array}$ & $\begin{array}{l}\text { Science \& } \\
\text { Engineering }\end{array}$ & $\begin{array}{l}\text { ANOVA } \\
\text { Significance } \\
\text { Level }\end{array}$ \\
\hline $\begin{array}{l}\text { Interest in commercialisation of } \\
\text { research results (CRR) }\end{array}$ & 4.39 & 4.70 & 5.30 & .000 \\
\hline In favour of CRR & 4.85 & 5.46 & 5.99 & .000 \\
\hline $\begin{array}{l}\text { Possible for me to combine research } \\
\text { and CRR }\end{array}$ & 4.06 & 3.87 & 4.55 & .001 \\
\hline $\begin{array}{l}\text { Willingness to CRR within own } \\
\text { research area }\end{array}$ & 4.11 & 4.41 & 4.83 & .001 \\
\hline $\begin{array}{l}\text { Central administration is supportive } \\
\text { towards researchers' possibilities to } \\
\text { CRR }\end{array}$ & 4.49 & 4.37 & 4.40 & .681 \\
\hline $\begin{array}{l}\text { My faculty is supportive towards } \\
\text { researchers' possibilities to CRR }\end{array}$ & 4.01 & 4.08 & 4.54 & .000 \\
\hline $\begin{array}{l}\text { My department is supportive towards } \\
\text { researchers' possibilities to CRR }\end{array}$ & 3.93 & 3.95 & 4.61 & .000 \\
\hline $\begin{array}{l}\text { My division is supportive towards } \\
\text { researchers' possibilities to CRR }\end{array}$ & 3.50 & 3.96 & 4.72 & .000 \\
\hline $\begin{array}{l}\text { My research group level is supportive } \\
\text { towards researchers' possibilities to } \\
\text { CRR }\end{array}$ & 4.01 & 4.10 & 4.87 & .000 \\
\hline $\begin{array}{l}\text { My } \mathrm{PhD} \text { supervisor is supportive } \\
\text { towards researchers' possibilities to } \\
\text { CRR }\end{array}$ & 4.30 & 4.15 & 4.92 & .000 \\
\hline
\end{tabular}

Students were also asked about their perceptions whether the university environment is supportive to CRR. All levels of the university hierarchy, starting with central administration and faculty level, down to the research group and $\mathrm{PhD}$ supervisor, were scored by the respondents.

Students from all faculties perceived the central administration level as supportive towards researchers' possibilities to engage in CRR (scores range from 4.37 to 4.49; differences between faculties were not significant, see Table 1). Furthermore, the faculty level was seen as supportive across the board and the same can be said about the PhD students' everyday contexts, i.e. the research groups and the supervisors.

The middle levels (i.e. department and division levels) were perceived as slightly unsupportive (scores ranging from 3.50 to 3.96) by PhD students at the faculties of Arts \& Humanities (including Social and Educational Sciences) and Health Sciences. 
On almost all levels, students from the faculty of Science \& Engineering experienced the university environment as most supportive (scores range from 4.54 to 4.92 ). This group of $\mathrm{PhD}$ students perceived increasing supportiveness further down in the hierarchical levels, where own supervisor is deemed the most supportive on average.

\subsection{Mobility during PhD education}

The second research question addresses mobility as a way of forming networks and stimulating flexibility and entrepreneurial behaviour within the $\mathrm{PhD}$ education. Table 2 shows the extent of mobility defined as a period of time spent at a workplace other than the $\mathrm{PhD}$ student's daily workplace, for example another university, a public organisation or a private firm. A first observation is that one quarter $(25.7 \%)$ of the respondents have experienced mobility as a part of their $\mathrm{PhD}$ education. In these instances $\mathrm{PhD}$ students are always required to have a main academic supervisor affiliated to the home university. In addition to that it is not unusual that there is an assistant supervisor who may be employed by an organisation outside the university such as a partner organisation.

$\mathrm{PhD}$ students from the faculty of Science \& Engineering are undertaking mobility placements within the private sector to a higher extent than $\mathrm{PhD}$ students at other faculties. Students at the faculties of Arts \& Humanities (including Social and Educational Sciences) and Health Sciences are on the other hand undertaking slightly more mobility placements at both other universities and public organisations. 
Table 2. Extent of mobility during PhD education (number of individuals provided in brackets).

\begin{tabular}{|l|l|l|l|l|l|}
\hline Direction of Mobility & No mobility & $\begin{array}{l}\text { University } \\
\text { and/or } \\
\text { research } \\
\text { organisation }\end{array}$ & $\begin{array}{l}\text { Public } \\
\text { organisation } \\
\text { or public } \\
\text { organisation } \\
\text { and } \\
\text { university }\end{array}$ & $\begin{array}{l}\text { Firm } \\
\text { or firm and } \\
\text { public } \\
\text { organisation } \\
\text { or firm and } \\
\text { university }\end{array}$ & Total \\
\hline $\begin{array}{l}\text { Arts \& Humanities (including } \\
\text { Social and Educational Sciences) }\end{array}$ & $71 \%(73)$ & $16 \%(17)$ & $8 \%(8)$ & $5 \%(5)$ & $100 \%(103)$ \\
\hline Health Sciences & $75 \%(119)$ & $16 \%(25)$ & $6 \%(10)$ & $3 \%(4)$ & $100 \%(158)$ \\
\hline Science \& Engineering & $75 \%(150)$ & $13 \%(25)$ & $1 \%(3)$ & $11 \%(21)$ & $100 \%(199)$ \\
\hline Total & $74 \%(342)$ & $15 \%(67)$ & $5 \%(21)$ & $6 \%(30)$ & $100 \%(460)$ \\
\hline
\end{tabular}

Regarding correlations between mobility and interest in CRR the survey results show that the group with mobility placements at other universities was the least interested in CRR (average score 4.52), while those with placements at firms were most interested (average score 5.63; see Appendix Table A1). Regarding correlations to perceived supportiveness significant differences were found between the groups on the level of research group. $\mathrm{PhD}$ students with mobility placements at other universities experienced least support from their research groups when it comes to CRR (average score 4.18), whereas $\mathrm{PhD}$ students that have spent a part of their $\mathrm{PhD}$ education at firms perceived their research groups as most supportive (average score 5.07).

\subsection{External collaborations during PhD education}

The final research question deals with the extent of external collaborations as a part of $\mathrm{PhD}$ education as well as possible correlations between collaboration and opinions concerning CRR. Collaboration was defined in the survey as collaborative projects or partnerships with organisations outside the university. It is notable that the majority of respondents $(61.3 \%)$ are involved or have been involved in external collaboration during their doctoral education.

Table 3 shows that $\mathrm{PhD}$ students from the faculties of Arts \& Humanities (including Social and Educational Sciences) and Health Sciences are more involved in collaborations with the public sector than those from Science \& Engineering. Collaborations both with other universities (including research organisations) and with firms are more common at the faculty of Science \& Engineering. 
Table 3. Extent of external collaborations during $\mathrm{PhD}$ education (number of individuals provided in brackets).

\begin{tabular}{|l|l|l|l|l|l|}
\hline \multicolumn{1}{|c|}{$\begin{array}{l}\text { Collaborative } \\
\text { partner(s) }\end{array}$} & $\begin{array}{l}\text { No } \\
\text { collaboration }\end{array}$ & $\begin{array}{l}\text { University } \\
\text { and/or } \\
\text { research } \\
\text { organisation }\end{array}$ & $\begin{array}{l}\text { Public } \\
\text { organisation } \\
\text { or public } \\
\text { organisation } \\
\text { and } \\
\text { university }\end{array}$ & $\begin{array}{l}\text { Firm } \\
\text { or firm and } \\
\text { public } \\
\text { organisation } \\
\text { or firm and } \\
\text { university }\end{array}$ & Total \\
\hline Faculty affiliation & $43 \%(44)$ & $15 \%(15)$ & $26 \%(27)$ & $16 \%(16)$ & $100 \%(102)$ \\
\hline $\begin{array}{l}\text { Arts \& Humanities (including } \\
\text { Social and Educational Sciences) }\end{array}$ & $46 \%(72)$ & $18 \%(29)$ & $23 \%(36)$ & $13 \%(20)$ & $100 \%(157)$ \\
\hline Health Sciences & $31 \%(61)$ & $22 \%(43)$ & $4 \%(9)$ & $43 \%(85)$ & $100 \%(198)$ \\
\hline Science \& Engineering & $39 \%(177)$ & $19 \%(87)$ & $16 \%(72)$ & $26 \%(121)$ & $100 \%(457)$ \\
\hline Total & $\mathrm{p}=0.000$ & & & \\
\hline Pearson Chi-Square $=71.8$ & & & &
\end{tabular}

When it comes to differences in opinions concerning CRR between the defined collaboration categories it is notable that both interest in and a positive mindset towards CRR varies significantly between the groups. The average scores for interest in CRR range from 4.70 to 5.28 with the lowest score found in the group not involved in collaboration at all. Concerning respondents' opinions on being in favour of CRR the group collaborating with the public sector was least in favour of CRR while those collaborating with firms were most positive (scores range between 5.28 and 5.95; see Appendix Table $\mathrm{A} 2)$.

Regarding the perceived supportiveness of the university context related to category of collaboration, there were significant differences between the categories on all levels except the highest administrative level (which was deemed as slightly supportive by all groups). PhD students collaborating with firms perceived the university environment at all other levels (from faculty to supervisor) as more supportive than any other group (average scores range from 4.58 for faculty to 5.10 for supervisor with scores increasing towards lower hierarchical levels). In addition, those collaborating with public organisations have the lowest scores throughout all levels except central administration level. The scores for this group range between 3.78 for division and 4.14 for supervisor, thus experiencing the university context as unsupportive apart from the supervisor level.

\section{Concluding discussion and implications}

In this paper we have examined $\mathrm{PhD}$ students' opinions on commercialisation of research results and their perceptions of the supportiveness of university context in this regard, as well as the role of 
mobility and collaborations with external actors in PhD education. These topics have not been simultaneously addressed in earlier studies, although they are highly relevant for the discussions concerning both knowledge-based regional development and the universities' entrepreneurial role. In the following we present four broad conclusions from this study.

Firstly, PhD students from all faculties are on average slightly positive towards commercialisation of research results (CRR). PhD students from the faculty of Arts \& Humanities express relatively lowest interest while those from Science \& Engineering relatively highest. This is in line with the study by Harman (2002) which for example indicated that a majority of PhD students (around 80 percent) believed that their career opportunities could be enhanced through industrial links. Our results show that the development towards the entrepreneurial university is fairly well established among the future academic staff, which will have an impact on the strategic orientation of universities in the coming decades. The faculty of Health Sciences constitutes a special case since the PhD students there show high interest in and willingness to CRR, but they state that their possibilities to concurrently engage in both research and CRR are limited. Faculty-specific characteristics might be a contributing cause for this, for example a highly regulated and planned process of $\mathrm{PhD}$ education allowing for very few excursions off the beaten path. Furthermore, the health care industry seems to prefer recruitment of graduated $\mathrm{PhDs}$ rather than engagement in research partnerships with individual academics.

Secondly, the university context is perceived as slightly supportive towards CRR, except for the middle levels (i.e. department and division levels) at the faculties of Arts \& Humanities (incl. Social and Educational Sciences) and Health Sciences. The highest and the lowest hierarchical levels are deemed most supportive. This indicates that both "bottom-up" and "top-down" processes in support of commercialisation are in place, however they are hindered at the middle level which has not been fully incorporated into the entrepreneurial strategy of the university. Other scholars have called for structural changes, e.g. legislative, in order to facilitate CRR (Baldini et al. 2006) paired with changes in everyday work and culture (Chrisman et al. 1995, Debackere and Veugelers 2005, Rasmussen et al. 2006). Our results lead to the conclusion that the middle levels should also be carefully considered as they can be an obstacle as well as a catalyst for commercialisation activities. Lower supportiveness of the middle levels could perhaps be viewed as a manifestation of the tension caused by the perceived infringement of commercialisation on academic goals such as publication rate and completion of $\mathrm{PhD}$ projects. However, it is important to note that previous studies have shown a positive relation between 
commercialisation activities and both publishing rate and quality, in Europe as well as in US

(Czarnitzki et al. 2007; Lowe and Gonzalez-Brambila 2007).

Thirdly, concerning mobility placements of PhD students, one quarter have spent time outside their home university as a part of their $\mathrm{PhD}$ education. Science \& Engineering $\mathrm{PhD}$ students are more frequently undertaking mobility placements within the private sector, whilst $\mathrm{PhD}$ students from Health Sciences and Art \& Humanities (incl. Social and Educational Sciences) are more mobile to other universities and public sector organisations. The direction of mobility is correlated with interest in CRR, in such way that PhD students spending time at firms are most interested in CRR while those spending time at other universities are the least interested. Thus, it is not the mobility per se that is related to interest in CRR, but rather its direction. One possible interpretation is that PhD students interested in an academic career that pursue linkages with other universities see CRR as incompatible with this type of career. This career outlook could be related to the setup of the national academic system (Etzkowitz 2003) as well as to specific disciplines being more restrictive or more open (Etzkowitz et al. 2000). Simultaneously, industry might exhibit a lack of understanding of the academic context, e.g. what it can offer and on what terms (Siegel et al. 2003). The overwhelming majority of PhD students are not mobile during their doctoral education. Previous studies have shown that this could be caused by lack of time, funding, motivation or internal support, as well as avoidance of delays in research programmes and also personal obligations (Kyvik et al. 1999).

Fourthly, when it comes to $\mathrm{PhD}$ students' collaborations with organisations outside their home university it has been shown that the majority of $\mathrm{PhD}$ students are engaged in external collaborations. However, there are differences between faculties in the type of collaboration partners. Firms and other universities are more frequently collaborating with the faculty of Science \& Engineering whereas $\mathrm{PhD}$ students from the other faculties are more associated with public organisations. Interest in CRR is lowest amongst those not involved in collaboration at all. This simultaneous low level of interest and lack of collaborations might have several causes, for example elements of insularity in various parts of the university organisation, or requirements from the financing bodies. Jacob et al. (2003) have for example shown that in universities with a high degree of public financing there are concerns that the image of the university might be adversely affected by extensive CRR activities.

Several implications for policymakers as well as leaders in academic institutions follow from the results presented here. As there already exists an interest for commercialisation among a wide 
population of $\mathrm{PhD}$ students from different disciplines it is important to enhance the force this interest represents through carefully designed strategies and activities encompassing the whole university environment. Such strategies should be tailored to suit a particular university context and the institutional culture (Kezar and Eckel 2002). The departments and divisions, i.e. the middle levels of the university hierarchy, need to be involved in supporting CRR and other entrepreneurial activities. This could include implementing incentive mechanisms and evaluation criteria which take into account commercial potential and industry relevance of research (Debackere and Veugelers 2005). This could send strong signals that it is desirable and valuable to combine academic career with CRR efforts.

Another implication is that there is scope for improving the conditions for mobility during $\mathrm{PhD}$ education, e.g. dedicated funding, devoted time for mobility and internal support that gives mobility a status as a natural part of the education. Such development would facilitate PhD students' access to networks and promote a flexible mindset. Finally, it is important to reach out and engage all groups of PhD students, even those with lower interest in CRR and few contacts with external organisations. Reaching this group of $\mathrm{PhD}$ students is one of the major challenges when it comes to the development of the entrepreneurial university. This follows from the current state of academic environment where flexibility and openness is a necessary part, for example when applying for research funding or engaging in multidisciplinary projects and reaching out with one's research results (Scott 1997; Etzkowitz et al. 2000).

In practice, mobility, collaboration and CRR skills could be implemented in most $\mathrm{PhD}$ programmes, for example through courses, graduate schools or interactive research design (Aagaard Nielsen and Svensson 2006; Bienkowska and Klofsten 2009). One successful example is a PhD course called ETP (Entrepreneurship in Theory and Practice) run at Linköping University that spans faculty borders reaching PhD students from Health Sciences, Art \& Humanities as well as Science \& Technology. It provides a creative and stimulating arena where twenty PhD students per year test their own ideas in multi-disciplinary teams and find out about the practicalities and rules surrounding commercialisation. PhD students involved in such courses and programmes could serve as inspiration and role models for new and prospective $\mathrm{PhD}$ students, while at the same time strengthening the ties between academia and other parts of the society. Over time, such ties could stimulate recognition of opportunity in a broad sense as well as encourage various types of entrepreneurial behaviour, also interwoven with an academic career. 


\section{Acknowledgements}

The authors would like to thank HELIX VINN Excellence Centre for financial support of the project and the $\mathrm{PhD}$ students of Linköping University for responding to the survey. We are also grateful to three anonymous peer reviewers for providing us with most valuable comments.

\section{Appendix}

See tables 4 and 5 .

Table 4. PhD students' opinions categorised according to type of mobility placement (tested for significant differences between groups).

\begin{tabular}{|l|l|l|l|l|l|}
\hline \multicolumn{1}{|c|}{ Mobility type } & No mobility & $\begin{array}{l}\text { University } \\
\text { and/or } \\
\text { research } \\
\text { organisation }\end{array}$ & $\begin{array}{l}\text { Public } \\
\text { organisation } \\
\text { or public } \\
\text { organisation } \\
\text { and } \\
\text { university }\end{array}$ & $\begin{array}{l}\text { Firm } \\
\text { or firm and } \\
\text { public } \\
\text { organisation } \\
\text { or firm and } \\
\text { university }\end{array}$ & $\begin{array}{l}\text { ANOVA } \\
\text { significance } \\
\text { level }\end{array}$ \\
\hline $\begin{array}{l}\text { Interest in commercialisation } \\
\text { of research results (CRR) }\end{array}$ & 4.88 & 4.52 & 5.09 & 5.63 & 0.042 \\
\hline In favour of CRR & 5.56 & 5.34 & 5.27 & 6.07 & 0.150 \\
\hline \hline $\begin{array}{l}\text { Central administration is } \\
\text { supportive towards } \\
\text { researchers' possibilities to } \\
\text { CRR }\end{array}$ & 4.45 & 4.39 & 4.09 & 4.23 & 0.364 \\
\hline $\begin{array}{l}\text { My faculty is supportive } \\
\text { towards researchers' } \\
\text { possibilities to CRR }\end{array}$ & 4.29 & 4.23 & 4.23 & 4.13 & 0.882 \\
\hline $\begin{array}{l}\text { My department is supportive } \\
\text { towards researchers' } \\
\text { possibilities to CRR }\end{array}$ & 4.25 & 4.12 & 4.14 & 4.37 & 0.741 \\
\hline $\begin{array}{l}\text { My division is supportive } \\
\text { towards researchers' } \\
\text { possibilities to CRR }\end{array}$ & 4.27 & 4.15 & 4.36 & 4.57 & 0.507 \\
\hline $\begin{array}{l}\text { My research group level is } \\
\text { supportive towards } \\
\text { researchers' possibilities to } \\
\text { CRR }\end{array}$ & 4.40 & 4.18 & 4.45 & 5.07 & 0.042 \\
\hline $\begin{array}{l}\text { My PhD supervisor is } \\
\text { supportive towards } \\
\text { researchers' possibilities to } \\
\text { CRR }\end{array}$ & 4.50 & 4.30 & 4.64 & 5.03 & 0.154 \\
\hline
\end{tabular}


Table 5. PhD students' opinions categorised according to type of collaboration (tested for significant differences between groups).

\begin{tabular}{|c|c|c|c|c|c|}
\hline Opinions \& Context & $\begin{array}{l}\text { No } \\
\text { collaboration }\end{array}$ & $\begin{array}{l}\text { University } \\
\text { and/or } \\
\text { research } \\
\text { organisation }\end{array}$ & $\begin{array}{l}\text { Public } \\
\text { organisation } \\
\text { or public } \\
\text { organisation } \\
\text { and } \\
\text { university }\end{array}$ & $\begin{array}{l}\text { Firm } \\
\text { or firm and } \\
\text { public } \\
\text { organisation } \\
\text { or firm and } \\
\text { university }\end{array}$ & $\begin{array}{l}\text { ANOVA } \\
\text { Significance } \\
\text { Level }\end{array}$ \\
\hline $\begin{array}{l}\text { Interest in } \\
\text { commercialisation of } \\
\text { research results (CRR) }\end{array}$ & 4.70 & 4.77 & 4.82 & 5.28 & 0.042 \\
\hline In favour of CRR & 5.37 & 5.59 & 5.28 & 5.95 & 0.004 \\
\hline $\begin{array}{l}\text { Central administration is } \\
\text { supportive towards } \\
\text { researchers' possibilities to } \\
\text { CRR }\end{array}$ & 4.33 & 4.38 & 4.44 & 4.54 & 0.424 \\
\hline $\begin{array}{l}\text { My faculty is supportive } \\
\text { towards researchers' } \\
\text { possibilities to CRR }\end{array}$ & 4.15 & 4.30 & 3.97 & 4.58 & 0.001 \\
\hline $\begin{array}{l}\text { My department is supportive } \\
\text { towards researchers' } \\
\text { possibilities to CRR }\end{array}$ & 4.12 & 4.22 & 3.82 & 4.64 & 0.000 \\
\hline $\begin{array}{l}\text { My division is supportive } \\
\text { towards researchers' } \\
\text { possibilities to CRR }\end{array}$ & 4.17 & 4.27 & 3.78 & 4.72 & 0.000 \\
\hline $\begin{array}{l}\text { My research group level is } \\
\text { supportive towards } \\
\text { researchers' possibilities to } \\
\text { CRR }\end{array}$ & 4.22 & 4.44 & 3.83 & 5.01 & 0.000 \\
\hline $\begin{array}{l}\text { My PhD supervisor is } \\
\text { supportive towards } \\
\text { researchers' possibilities to } \\
\text { CRR }\end{array}$ & 4.27 & 4.48 & 4.14 & 5.10 & 0.000 \\
\hline
\end{tabular}

\section{References}

Aagaard Nielsen, K., and Svensson, L. G. (eds.) (2006). Action Research and Interactive Research: Beyond Practice and Theory. Maastricht: Shaker Publishing.

Aldrich, H., Rosen, B., and Woodward, W. (1987). The Impact of Social Networks on Business Foundings and Profit: A Longitudinal Study. In N. C. Churchil, J. A. Hornaday, B. A. Kirchhoff, O. J. Krasner, and K. H. Vesper (eds.), Frontiers of Entrepreneurship Research. Proceedings of the Seventh Annual Babson College Entrepreneurship Research Conference. Wellesley, MA: Babson College.

Altbach, P. G. (2001). Academic freedom: International realities and challenges. Higher Education, 41(1), 205-219.

Avveduto, S. (2001). International mobility of PhDs. In OECD (Organisation for Economic Cooperation and Development), Innovative People. Mobility of Skilled Personnel in National Innovation Systems (pp. 229-242). Paris: OECD Publications.

Baldini, N., Grimaldi, R., and Sobrero, M. (2006). Institutional changes and the commercialization of academic knowledge: A study of Italian universities' patenting activities between 1965 and 2002. Research Policy, 35(4), 518-532.

Barnes, T., Pashby, I., and Gibbons, A. (2002). Effective University - Industry Interaction: A Multicase Evaluation of Collaborative R\&D Projects. European Management Journal, 20(3), 272285. 
Bergek, A., and Norrman, C. (2008). Incubator best practice: A framework. Technovation, 28(1-2), 2028.

Bienkowska, D., and Klofsten, M. (2009). 'Entrepreneurship and the PhD: A case study of a doctoral mobility program', Paper presented at Triple Helix VII Conference, June 17-19, Glasgow.

Bienkowska, D., Larsen, K., and Sörlin, S. (2010). Public-private innovation: Mediating roles and ICT niches of industrial research institutes. Innovation: Management, Policy \& Practice, 12(2), 206-216.

Bienkowska, D., Lundmark, M., and Malmberg, A. (2011). Brain circulation and flexible adjustment: Labour mobility as a cluster advantage. Geografiska Annaler: Series B, Human Geography, 93(1), 21-39.

Boden, D., Borrego, M., and Newswander, L. (2011). Student socialization in interdisciplinary doctoral education. Higher Education, 62(6), 741-755.

Bond, R., and Paterson, L. (2005). Coming down from the Ivory Tower? Academics' Civic and Economic Engagement with the Community. Oxford Review of Education, 31(3), 331-351.

Butcher, J., and Jeffrey, P. (2007). A view from the coal face: UK research student perceptions of successful and unsuccessful collaborative projects. Research Policy, 36(8), 1239-1250.

Carlson, W. B. (1988). Academic Entrepreneurship and Engineering Education: Dugald C. Jackson and the MIT-GE Cooperative Engineering Course, 1907-1932. Technology and Culture, 29(3), 536-567.

Chrisman, J. J., Hynes, T., and Fraser, S. (1995). Faculty entrepreneurship and economic development: The case of the University of Calgary. Journal of Business Venturing, 10(4), 267-281.

Clark, B. R. (1998). Creating Entrepreneurial Universities: Organizational Pathways of Transformation. Oxford: Pergamon Press.

Cowen, R. (1991). The Management and Evaluation of the Entrepreneurial University: The Case of England. Higher Education Policy, 4(3), 9-13.

Czarnitzki, D., Glänzel, W., and Hussinger, K. (2007). Patent and publication activities of German professors: an empirical assessment of their co-activity. Research Evaluation, 16(4), 311-319.

Dasgupta, P., and David, P. A. (1994). Toward a new economics of science. Research Policy, 23(5), 487-521.

Debackere, K., and Veugelers, R. (2005). The role of academic technology transfer organizations in improving industry science links. Research Policy, 34(3), 321-342.

Enders, J. (2002). Serving many masters: The PhD on the labour market, the everlasting need of inequality, and the premature death of humboldt. Higher Education, 44(3), 493-517.

Etzkowitz, H. (1983). Entrepreneurial scientists and entrepreneurial universities in American academic science. Minerva, 21(2), 198-233.

Etzkowitz, H. (2003). Research groups as 'quasi-firms': the invention of the entrepreneurial university. Research Policy, 32(1), 109-121.

Etzkowitz, H., and Klofsten, M. (2005). The innovating region: toward a theory of knowledge-based regional development. $R \& D$ Management, 35(3), 243-255.

Etzkowitz, H., and Leydesdorff, L. (1995). The Triple Helix - University-Industry-Government Relations: A Laboratory for Knowledge Based Economic Development. EASST Review, 14(1), 14-19.

Etzkowitz, H., and Leydesdorff, L. (2000). The dynamics of innovation: from National Systems and "Mode 2" to a Triple Helix of university-industry-government relations. Research Policy, 29(2), 109-123.

Etzkowitz, H., Webster, A., Gebhardt, C., and Terra, B. R. C. (2000). The future of the university and the university of the future: evolution of ivory tower to entrepreneurial paradigm. Research Policy, 29(2), 313-330.

Fisher, D., and Atkinson-Grosjean, J. (2002). Brokers on the boundary: Academy-industry liaison in Canadian universities. Higher Education, 44(3), 449-467.

Fornahl, D. (2003). Entrepreneurial activities in a regional context. In D. Fornahl and T. Brenner (eds.), Cooperation, Networks and Institutions in Regional Innovation Systems (pp. 38-57). Cheltenham, UK: Edward Elgar.

Gartner, W. B. (1988). "Who is an Entrepreneur?" Is the Wrong Question. American Journal of Small Business, 12(4), 11-32.

Gibb, A., and Hannon, P. (2006). Towards the entrepreneurial university? International Journal of Entrepreneurship Education, 4, 73-110.

Gibbons, M., Limoges, C., Nowotny, H., Schwartzman, S., Scott, P., and Trow, M. (1994). The new production of knowledge: the dynamics of science and research in contemporary societies. London: SAGE. 
Granovetter, M. S. (1974). Getting a Job: A Study of Contacts and Careers. Cambridge, MA: Harvard University Press.

Granovetter, M. (1985). Economic action and social structure: The problem of embeddedness. American Journal of Sociology, 91(3), 481-510.

Harman, G. (1999). Australian science and technology academics and university-industry research links. Higher Education, 38(1), 83-103.

Harman, K. (2002). The Research Training Experiences of Doctoral Students Linked to Australian Cooperative Research Centres. Higher Education, 44(3), 469-492.

Harman, K. (2004). Producing 'industry-ready' doctorates: Australian Cooperative Research Centre approaches to doctoral education. Studies in Continuing Education, 26(3), 387-404.

Henkel, M. (2000). Academic identities and policy change in higher education. London: Jessica Kingsley Publishers.

Henkel, M. (2005). Academic identity and autonomy in a changing policy environment. Higher Education, 49(1), 155-176.

Jacob, M. (2001). Managing the Institutionalisation of Mode 2 Knowledge Production. Science Studies, 14(2), 83-100.

Jacob, M., Lundqvist, M., and Hellsmark, H. (2003). Entrepreneurial transformations in the Swedish University system: the case of Chalmers University of Technology. Research Policy, 32(9), $1555-1568$.

Jöns, H. (2009). 'Brain circulation' and transnational knowledge networks: studying long-term effects of academic mobility to Germany, 1954-2000. Global Networks, 9(3), 315-338.

Kezar, A. J., and Eckel, P. D. (2002). The Effect of Institutional Culture on Change Strategies in Higher Education: Universal Principles or Culturally Responsive Concepts? The Journal of Higher Education, 73(4), 435-460.

Klofsten, M., Heydebreck, P., and Jones-Evans, D. (2010). Transferring good practice beyond organizational borders: Lessons from transferring an entrepreneurship programme. Regional Studies, 44(6), 791-799.

Klofsten, M., and Jones-Evans, D. (2000). Comparing Academic Entrepreneurship in Europe - The Case of Sweden and Ireland. Small Business Economics, 14(4), 299-309.

Kyvik, S., Karseth, B., and Blume, S. (1999). International mobility among Nordic doctoral students. Higher Education, 38(4), 379-400.

Li, H. (2010). Higher education in China: Complement or competition to US universities? In C. T. Clotfelter (ed.), American universities in a global market (pp. 269-304). Chicago: The University of Chicago Press.

Liebeskind, J. P., Oliver, A. L., Zucker, L., and Brewer, M. (1996). Social Networks, Learning, and Flexibility: Sourcing Scientific Knowledge in New Biotechnology Firms. Organization Science, 7(4), 428-443.

Lowe, R., and Gonzalez-Brambila, C. (2007). Faculty Entrepreneurs and Research Productivity. The Journal of Technology Transfer, 32(3), 173-194.

Magnusson, M., McKelvey, M., and Versiglioni, M. (2009). The forgotten individuals: attitudes and skills in academic commercialization in Sweden. In M. McKelvey and M. Holmén (eds.), Learning to Compete in European Universities (pp. 219-250). Cheltenham, UK: Edward Elgar.

Mosey, S., Lockett, A., and Westhead, P. (2006). Creating network bridges for university technology transfer: The medici fellowship programme. Technology Analysis \& Strategic Management, 18(1), $71-91$.

Nohria, N., and Eccles, R. G. (eds.) (1992). Networks and Organizations: Structure, Form, and Action. Boston: Harvard Business School Press.

Nowotny, H., Scott, P., and Gibbons, M. (2003). Introduction: 'Mode 2' Revisited: The New Production of Knowledge. Minerva, 41(3), 179-194.

Paul, J.-J., and Perret, C. (2001). 'The reforms of post graduate studies in France: a story of a forced marriage', Paper presented at Postgraduate education in Europe - Past, present and future Conference, May 4-5, Linköping.

Rasmussen, E., Moen, Ø., and Gulbrandsen, M. (2006). Initiatives to promote commercialization of university knowledge. Technovation, 26(4), 518-533.

Salminen-Karlsson, M., and Wallgren, L. (2008). The interaction of academic and industrial supervisors in graduate education. Higher Education, 56(1), 77-93.

Santoro, M. D. (2000). Success breeds success: The linkage between relationship intensity and tangible outcomes in industry-university collaborative ventures. The Journal of High Technology Management Research, 11(2), 255-273. 
Saxenian, A. (1994). Regional Advantage: Culture and Competition in Silicon Valley and Route 128. Cambridge, MA: Harvard University Press.

Scott, P. (1997). The changing role of the university in the production of new knowledge. Tertiary Education and Management, 3(1), 5-14.

Shane, S. (2004). Academic Entrepreneurship: University Spinoffs and Wealth Creation. Cheltenham, UK: Edward Elgar.

Shane, S., and Cable, D. (2002). Network Ties, Reputation, and the Financing of New Ventures. Management Science, 48(3), 364-381.

Siegel, D. S., Waldman, D. A., Atwater, L. E., and Link, A. N. (2003). Commercial knowledge transfers from universities to firms: improving the effectiveness of university-industry collaboration. The Journal of High Technology Management Research, 14(1), 111-133.

Slaughter, S., and Leslie, L. L. (1997). Academic Capitalism: Politics, Policies, and the Entrepreneurial University. Baltimore: The Johns Hopkins University Press.

Starbuck, E. (2001). Optimizing University Research Collaborations. Research-Technology Management, 44(1), 40-44.

Storper, M., and Venables, A. J. (2004). Buzz: face-to-face contact and the urban economy. Journal of Economic Geography, 4(4), 351-370.

Thune, T. (2009). Doctoral students on the university-industry interface: a review of the literature. Higher Education, 58(5), 637-651.

Thune, T. (2010). The Training of "Triple Helix Workers"? Doctoral Students in University-IndustryGovernment Collaborations. Minerva, 48(4), 463-483.

University of Wales Global Academy. (2011). What is POWIS? http://www.globalacademy.org.uk/powis. Accessed 4 March 2011.

Urry, J. (2002). Mobility and Proximity. Sociology, 36(2), 255-274.

Zellner, C., and Fornahl, D. (2002). Scientific knowledge and implications for its diffusion. Journal of Knowledge Management, 6(2), 190-198. 